\title{
Ei-inhimilliset eläimet osana aatedraaman rakentumista Laura Ruohosen näytelmissä Lintu vai kala, Kuningatar K ja Luolasto
}

1 Johdanto

Olmi! Se ei poikkea meistä, yhtä paljas ja avuton, värisee himosta, elää ja kuolee. Kuinka pieniltä näyttävät sen tunteet kuinka merkityksettömiltä pyrkimykset. Ei ihme, että sitä kutsutaan luolien ihmiseksi. (Luolasto, 42).

Tuotteliaan ja kansainvälisestikin tunnetun näytelmäkirjailija Laura Ruohosen (s. 1960) näytelmiä on luonnehdittu aatedraamoiksi (esim. Ahola 2014). Aatedraama (drama of ideas, thesis play) on perinteisesti määritelty tiettyä aatetta ajavaksi tai tähdentäväksi näytelmäksi, joka pyrkii tarjoamaan jonkun ratkaisun johonkin yhteiskunnalliseen ongelmaan (Hosiaisluoma 2016, 14). Martin Puchner (2010) näkee modernin aatedraaman kehittyneen Platonin (427-347 eaa.) sokraattisten dialogien pohjalta. Monille moderneille aatedramaatikoille, kuten August Stridbergille, Luigi Pirandellolle ja Bertolt Brechtille, on tyypillistä draaman käyttäminen eräänlaisena epistemologisena välineenä, totuuden laboratoriona tai ajatuskokeena, joka voi konkretisoida ja toisaalta myös kehittää uutta ajattelua. (Puchner 2010, 73-75, 119.) Ellen Redlingin (2014) mukaan nykyajan aate- ja poliittiset draamat haastavat entistä enemmän katsojia omaan ajatteluun ja argumentointiin valmiiden vastausten sijaan. Keskeisiä sisältöjä ovat muun muassa sotaan, talouteen, ympäristöön, terveyteen ja monikansallisuuteen liittyvät teemat. (Redling 2014.)

Biologitaustaisen Ruohosen näytelmissä ihmisen ja ympäristön suhde on usein temaattisesti keskiössä. Hän käyttää paljon luontoympäristöjä näytelmiensä tapahtumapaikkoina tai hänen omine sanoineen "maisemina" (Ruohonen 2012). Tapahtumapaikat, kuten suo, saaret, meri ja luolat vaikuttavat näytelmien tapahtumiin ja näin myös kokonaisdramaturgiaan. Useissa Ruohosen näytelmissä viitataan eksplisiittisesti ihmisen 
luonnolle aiheuttamiin ongelmiin, kuten luonnon saastumiseen tai eläinten ${ }^{1}$ kuolemiseen sukupuuttoon. Eläimiin ja luontoon liittyvät viittaukset ovatkin tyypillistä Ruohosen poetiikkaa. (Lintunen 2012, 5-7.) Hänen näytelmissään eläimiä esiintyy paljon - pääasiassa dialogeissa ja monologeissa. Eläimiä ei ole kuitenkaan henkilöity ihmisen kaltaisiksi puhuviksi olioiksi lukuun ottamatta muutamaa lastennäytelmää. ${ }^{2}$ Tutkimuksen kannalta onkin yhtäältä kiinnostavaa, mitä merkityksiä eläimet tuottavat näytelmien sisältöön, ja toisaalta, miten eläimet on representoitu.

John Simons (2002, 87) kirjoittaa, että kaikki kirjallisuuden eläinrepresentaatiot ovat enemmän tai vähemmän antropomorfisia eli ihmisen kokemuksen kautta suodattuneita, jolloin ne eivät tee täysin oikeutta eläimille. Ruohosen näytelmissä antropomorfisuus korostuu, koska eläimet "todentuvat" lähinnä henkilöhahmojen puheissa. Ekokriitikko Randy Malamud (2009, 44-45) näkee kuitenkin tärkeänä, että eläinten esteettisessä esittämisessä noudatetaan tiettyjä eettisiä periaatteita, kuten esimerkiksi eläinten hahmottaminen omassa elinympäristössään, eläinten kunnioittaminen ja eläintuntemuksen ja -tietouden opettaminen. Kirjallisuudessa eläinten tuottamia merkityksiä on tutkinut muun muassa Janna Kantola. Hän on kehitellyt Veikko Huovisen tuotantoa tutkimalla eläinesitysten jäsentelyn, jossa hän pyrkii kuvaamaan ihmisen ja eläimen suhteen ilmenemistä esittämisen strategiana, ei niinkään luokittelemaan eläinesityksiä. Hänen jäsentelynsä on seuraava: 1) eläin saa ihmisen ominaisuuksia, 2) ihminen saa eläimen ominaisuuksia ja 3) eläin eläimenä tai ihminen eläimen äänitorvena. (Kantola 2014, 96-105.) Luontorunoutta tutkinut Tero Tähtinen (2012, 34-38) puolestaan nostaa esille ihmisen ja luonnon (eläinten) välille syntyvän jännitteen tuottamat poliittis-ekologiset painotukset, joissa korostuvat muun muassa ihmisen ja eläinten elintilojen vastakkaisuus ja päällekkäisyys sekä eläinten aktiivinen ja ei-hallittava toimijuus.

Ihmisen ja eläinten samankaltaisuuden ja erojen pohdinta onkin yksi keskeisiä teemoja eläinfilosofiassa ja kriittisessä eläintutkimuksessa, jotka ovat artikkelissani keskeisiä näkökulmia. Myös posthumanistisessa eläintutkimuksessa ja teoriassa ihmistä ei nähdä kategorisesti erillisenä muista eläinlajeista ja näin posthumanismi kytkeytyy myös moraalisia kysymyksiä painottavaan eläinfilosofiaan (Lummaa-Rojola 2014, 20). Työtäni voisi määritellä ekokriittiseksi kirjallisuudentutkimukseksi, sillä tutkin eläimiin liittyviä merkityksiä ja sitä, miten ne vaikuttavat tapoihimme kohdella luontoa (esim. Lahtinen-Lehtimäki 2008, 8). Elisa Aaltolan mukaan, eläinfilosofia on kehittynyt 1970-luvulla syntyneen eläinetiikan pohjalta. Eläinetiikassa keskeistä on eläinten moraalisen aseman tarkastelu ja se, kuinka ihmisen pitäisi kohdella muita eläimiä. Eläinfilosofiassa tarkastellaan eläimiin liittyviä filosofisia kysymyksiä, joissa eläin on ensisijainen tutkimuksen kohde eikä pelkkä väline ihmisyyden määrittämisessä. (Aaltola 2013, 21-23.) Kriittinen eläintutkimus (critical animal studies) sivuaa Aaltolan määrittelemää eläinfilosofian käsitettä. Matthew

1 Käytän jatkossa selkeyden vuoksi käsitteitä "ihminen" ja "eläin", vaikka inhimillinen ja ei-inhimillinen eläin kuvaisivat paremmin Ruohosen näkemystä ihmisen ja eläimen suhteesta.

2 Yökyöpelit 2011 ja Tippukivitapaus 2017. 
Calarco on jakanut kriittisen eläintutkimuksen kolmeen pääsuuntaukseen. Identiteettiteoriat (identity) korostavat ihmisen ja eläimen samanlaisia piirteitä ja vaatimusta tasavertaiseen kohteluun, jolloin keskiössä ovat eettiset kysymykset. Erilaisuusteoriat (difference) puolestaan painottavat sekä ihmisten että eläinten erityisyyttä ja erilaisuutta. Eroja on niin ihmisten kuin eläintenkin kesken. Tämä suuntaus vastustaa kaikenlaista kategorisointia. Kolmas suuntaus (indistinction) $)^{3}$ lähtee siitä, että ihmiset ovat eläimiä, ja se pyrkii purkamaan ihmiskeskeistä näkökulmaa ja rakenteita, jotka pitävät yllä eläimiin kohdistuvaa väkivaltaa. (Calarco 2015, 4-5.)

Draamassa puhetilanteet toteutuvat kahdella ontologisella tasolla: sisäinen kommunikaatiotilanne liittyy draaman henkilöiden väliseen kommunikaatioon, kun taas ulkoinen kommunikaatiotilanne liittyy näytelmäkirjailijan tekstin välityksellä tapahtuvaan kommunikointiin yleisön kanssa (Pfister 1988, 103-106; Steinby-Tanskanen 2013, 318). Aatedraaman kannalta kiinnostavia ovat erityisesti ulkoisessa kommunikaatiotilanteessa tapahtuvat eläindialogit ja -monologit, koska ne välittävät näytelmäkirjailijan viestejä katsojille. Viesteillä voi olla esimerkiksi referentiaalinen eli tietoa välittävä tai appellatiivinen eli suostutteleva funktio (Pfister 1988, 106-118). Suostutteleva funktio liittyy vaikuttamiseen, ja usein tunteilla on siinä suuri rooli. Aaltolan $(2015,91)$ mukaan tunteet ovatkin nousseet keskiöön nykyisessä eläinfilosofiassa: tunteet ovat moraalisen toimijuuden perusta. Hän näkee, että rationaalinen argumentointi ei ole riittävä ihmisten ja eläinten välisten suhteiden muuttamiseen, vaan tarvitaan affektiivista empatiaa, jolloin yksilö suuntautuu kohti toisen yksilön haluja ja kokemuksia. Toisaalta tarvitaan myös reflektiivistä empatiaa, jolloin reflektoidaan eläimiin liittyviä uskomuksia, kielellisiä merkityksiä, stereotypioita ja tunteita. Tällöin järjellisyys, harkinta ja rationaalinen jäsentäminen nivoutuvat osaksi empatiaa. (Aaltola 2015, 94-97.)

Tässä artikkelissani ehdotan, että Ruohosen näytelmien eläimiin liittyvät dialogit ja monologit (jatkossa eläinpuhe) sekä parenteesit tuovat esille eläinfilosofisia teemoja ja samalla ne ovat omalta osaltaan rakentamassa Ruohosen näytelmistä ihmisen ja luonnon suhdetta problematisoivia sekä luontoa ja sen merkitystä korostavia aatedraamoja. Kysyn: Millaisia ihmisten ja eläinten välisten suhteiden sekä itse eläinten merkityksiä eläinpuheet tuottavat sekä minkälaisia eläinfilosofisia painotuksia näytelmistä voi tulkita? Käytän aineistonani Ruohosen kolmea näytelmää kolmelta eri vuosikymmeneltä: Lintu vai kala (1992, jatkossa LVK), Kuningatar K (2003, jatkossa KK) ja Luolasto (2014, jatkossa L). Näytelmät ovat läpileikkaus Ruohosen runsaasta tuotannosta, ja ne antavat kuvan eläinten "rooleista" eri näytelmissä. Tulkitsen näytelmien eläinpuheita eläinfilosofian näkökulmasta. Käsittelen näytelmät ilmestymisjärjestyksessä: näin ne kuvaavat myös kirjoittamisajankohtansa eläimiin liittyvää eläinfilosofista ajattelua ja sen kehittymistä. Lopuksi perustelen eläinpuheiden merkitystä aatedraaman rakentumisessa.

3 Englanninkielinen sana indistinct tarkoittaa epäselvää. Nämä teoriat ovat lähellä posthumanismia. 


\section{2 "Nämä kaksi viikkoa ratkaisee yhden lajin kohtalon."”}

Ruohosen alkukauden tuotantoon kuuluva Lintu vai kala -näytelmä haastaa kysymyksen muotoon puetun nimensä mukaisesti pohtimaan eläinten kohteluun liittyviä valintojamme: lintu viittaa uhanalaisen eläinlajin suojeluun, kun taas kala eläinten jalostukseen ja hyötykäyttöön. Eläimet ovat näytelmän ytimessä toiminnan kohteina, jolloin eläinpuheilla on myös juonellinen funktio. Eläinetiikan kysymykset, joissa pohditaan eläinten moraalista asemaa ja sitä, miten ihmisten pitäisi kohdella muita elämiä, ovat edelleenkin tärkeitä eläinfilosofian sisältöjä (Aaltola 2013, 20). Näytelmän valinnat liittyvät myös tapahtumapaikan eli erämaapuiston säilyttämiseen luonnontilaisena, sillä suon alle ollaan suunnittelemassa luontokeskusta maanalaisine hisseineen. Näytelmän päähenkilö biologi Riikka on erämaapuiston johtaja, joka saa apulaisekseen entisen miesystävänsä niin ikään biologi Jiipeen. He työskentelevät yhdessä Lapin erämaasuolla tutkien harvinaisia metsähanhia ja samalla suojellen niiden pesintää munavarkailta. Jiipeen salaisena projektina on uuden siikalajin kehittäminen. Riikan ja Jiipeen näkemykset eläinten kohtelusta poikkeavat toisistaan. Tästä syntyy näytelmän keskeinen konflikti, johon kytkeytyvät myös henkilökohtaiset suhteet. Näytelmän lopussa luontokeskuksen rakennustyöt ovat alkaneet ja Riikan ja Jiipeen uusi yritys rakentaa suhde kariutuu.

Lintu vai kala alkaa Riikan eläinaiheisella monologilla. Monologi on tyypillinen keino ulkoisessa kommunikaatiotilanteessa, jossa katsojien tietoon halutaan tuoda joitain dialogissa hankalasti esille tuotavia asioita (Steinby-Tanskanen 2013, 327).

(Puhuu pieneen sanelukoneeseen.) Lampaita pidetään lempeinä eläiminä, jotka hiljaa mutustavat ruohoa ja kasvattavat villaa. Se on vakava erehdys. Lammas on nopea ja tehokas tappaja. Se puree pahaa-aavistamattomalta uhriltaan pään irti tai katkoo siltä jalat, niin ettei se pääse pakoon. Useimmiten lampaat tappavat lintuja. Eräillä Brittein saarilla, joilla ruoho on erityisen vihreää ja mehevää elää lampaita, jotka ovat erikoistuneet tiirojen metsästykseen. Saarilla sataa melkein aina ja mineraalit huuhtoutuvat mereen. Lampaat syövät linnunluita saadakseen kalkkia, lisääntyvät ja kasvattavat lisää pehmeää valkoista villaa. Sama pätee luultavasti poroihin. Ne saalistavat munia. Kukaan ei ole kyennyt selvittämään, miksi kiljuhanhi kaksikymmentäluvulla yhtäkkiä hävisi Suomesta. Poroja sen sijaan laiduntaa joka vuosi yhä suuremmat laumat hanhien pesimäsoilla. Niitäkin pidetään lempeinä eläiminä. Ei haluta uskoa, että suuri joukko laupiasnaamaisia laumaeläimiä voisi olla syyllisiä yhtään mihinkään. Lauman koko ja tyhmyys vapauttavat ne kaikesta vastuusta. Pelkään petolampaita. Parempia ovat kunnon viholliset. (LVK, 7.)

Riikan monologi on faktuaalinen kuvaus lampaiden ja porojen toiminnasta. Faktuaalisessa kuvauksessa pyritään siihen, että kuvaukset näyttävät kiistämättömiltä tosiasioilta

4 Käytän lukujen otsikoinnissa ko. näytelmän repliikkejä. 
(Jokinen 2016, 341). Monologissa on käytetty tunteisiin vaikuttavia retorisia keinoja, kuten esimerkiksi lauhkeina ja lempeinä pidettyjen eläinten vertaaminen tehokkaisiin ja julmiin tappajiin, jotka metsästävät suunnitelmallisesti ihmisten tapaan. Inhimillistäminen vahvistuu, kun puhutaan vielä lampaiden "naamoista" ja "vastuusta vapautumisesta". Toisaalta saamme tietää myös syyn eläinten käyttäytymiseen: tarve saada kalkkia ja näin tuottaa ihmisille "pehmeää valkoista villaa". Monologissa mainittu "kadonnut" kiljuhanhi ${ }^{5}$, joka on luokiteltu erittäin uhanlaiseksi Pohjoismaissa, ennakoi näytelmän sisältöä eli metsähanhen suojelua. Riikan lampaisiin ja poroihin liittyvä puhe viittaa todellisiin tapauksiin, joita on tapahtunut muutamilla eristetyillä saarilla. ${ }^{6}$ Vieraslajien tuhoava vaikutus alkuperäiseen lajistoon tulee esille myös Riikan kertoessa Stephensaaren linnuista: "Siellä on aikojen alusta elänyt pikkusia lentokyvyttömiä peukaloisia. Sitten majakanvartija yhtenä päivänä hankki kissan, joka söi ne kaikki. Myöhemmin hoksattiin, että siinä hävisi sukupuuttoon tieteelle tuntematon laji." (LVK, 24. $)^{7}$ Ihmisen ajattelematon toiminta voi aiheuttaa suuria tuhoja. Kotieläimiä onkin nimitetty ekokriittisessä tutkimuksessa ihmisten kulttuurisiksi "kanssarikollisiksi" (Garrard 2004, 149).

Viidennessä kohtauksessa Riikan toinen monologi tuo lisänäkökulman ihmisen toiminnan vaikutuksista lintupopulaatioihin:

(On löytänyt kuolleen lokin. Puhuu sanelukoneeseensa.) Lokkien käyttäytyminen on muuttunut. Ne eivät enää puolusta poikasiaan. Pesillä saa rauhassa käydä tunkeilijoita, munia ja poikasia hävitä, eikä se kiinnosta emoa. Monet lokkiemot eivät enää edes ruoki poikasiaan ja yrittävät estää muitakin emoja antamasta ruokaa omille poikasilleen. Näin myös emon, joka yhtäkkiä hajotti pesänsä ja söi omat munansa. Lokit näyttävät päällisin puolin aivan terveiltä, maasta löytyy kuitenkin kuolleita lintuja. (LVK, 22.)

Myös tämä faktuaalinen kuvaus lokeista vaikuttaa tunteisiin, kun lintuemot eivät puolusta poikasiaan ja syövät omia muniaan. Herää kysymys, mitä linnuille on tapahtunut ja miksi ne käyttäytyvät tällä tavalla. Lintujen käyttäytyminen ja kuolleiden lintujen löytyminen viittaavat luonnon saastumiseen, erilaisiin ympäristömyrkkyihin, joiden vaikutuksiin herättiin 1960-luvulla (esim. Haila-Lähde 2003, 11-12). Karoliina Lummaa (2010, 235), joka on tutkinut lintujen konkreettisuutta 1970-luvun ympäristörunoudessa, kirjoittaakin, että juuri linnuista tuli ympäristön saastumisen ja eläimiä uhkaavien vaarojen esikuvia, ennemerkkejä ja symboleita. Kumpikaan Riikan monologeista ei vie varsinaisesti draamaa eteenpäin, vaan ne luovat kontekstia näytelmälle. Samalla ne kertovat biologi Riikan perehtymisestä eläintensuojeluun.

Riikan aatemaailma tulee esille myös muissa luonto- ja eläindialogeissa. Riikka näkee, että eläinten elämä on moraalisesti yhtä arvokas kuin ihmisen (ks. Francione 2013, 125).

5 Ks. WWF: Kiljuhanhi.

6 Ks. Karlshuker: Bird-eating deer and flesh-eating sheep.

7 Ks. Stephens Island wren. 
Hän on huolissaan tiettyjen eläinten, tässä näytelmässä erityisesti metsähanhien, tilanteesta. Tulevaisuuden uhkakuvana on, että jäljelle jää vain kolme eläinmaailman selviytyjää: "torakka, rotta ja ihminen" (LVK, 24), kuten hän yhdessä repliikissään toteaa. Riikka näyttäytyy puheidensa ja toimintojensa perusteella kiihkeänä luonnonsuojelijana ja eläinten oikeuksien puolestapuhujana: "Nyt on joka tapauksessa niin, että nämä kaksi viikkoa ratkaisee yhden lajin kohtalon. Hanhien munat on vielä löysää massaa, ryöstäjille ne kelpaa vain tän lyhyen hetken kun sikiö ei ole vielä alkanut kehittyä.” (LVK, 26.) Näytelmän keskiössä oleva metsähanhi pesii pohjoisilla soilla, ja se on uhanalainen laji. ${ }^{8}$ Esimerkiksi munavarkaat ovat edelleen todellinen uhka monille harvinaisille lintulajeille. Metsähanhea uhkaavat myös soiden kuivatus ja turvetuotanto. Näytelmässä suon alle suunniteltua toimintakeskusta voi pitää suurena uhkana koko ekosysteemille ja aroille linnuille. Kuten Riikka toteaa: "Tämä erämaa on ainutlaatunen paikka. Täällä on eläimiä ja kasveja, joita ei ole enää missään muualla.” (LVK, 23.) Näytelmän loppupuolella hän kuulee suolle sijoittuvan luontohallin rakentamispäätöksestä, ja turhautuneena omaan toimintaansa hän toteaa, että "Maailma on tullut valmiiksi. Ihminen on vihdoin tehnyt luonnosta vihollisensa" (LVK, 74).

Toisen biologin eli Jiipeen näkemys eläimistä ja eläinten kohtelusta on erilainen kuin Riikan. Hän ei näe eläimillä olevan itseisarvoa, vaan niiden arvo mitataan suhteessa ihmiseen. Hän ihmetteleekin, miksi Riikka kiihkoilee "Yhden linnun takia, kun tosiasiassa pitäisi löytää ne lajit, joilla on edellytykset pysyä hengissä? Ja ellei niitä ole, kehittää uusia. Tän puiston takia itkeminen on yhtä turhaa kuin dinosaurusten tai jättiläislevien.” (LVK, 24.) Jiipee tekeekin työnsä ohella salaa jalostuskokeita harvinaisella siialla. Hänen tavoitteenaan on kehittää taloudellisesti tuottava kalalaji, "Joka kasvaa nopeammin, on isompi ja kestää saasteita paremmin kuin nää nykyiset lajit" (LVK, 17). Jiipee ei koe myöskään lajien vähenemistä eikä elinympäristöjen tuhoutumista ongelmallisena. Toisaalta hän näkee eläinkokeet tärkeinä, koska kokeiden tulosten avulla voidaan löytää keinoja, jotka parantavat "ihmisen elämisen edellytyksiä" (LVK, 37). Hänen mielestään "on rikollista auttaa yhä sairaampia lapsia syntymään" (LVK, 37). Hän käyttääkin esimerkkinään omaa veljeään, joka on vaikeasti vammainen. Ironiseen sävyyn hän arvottaa veljensä elämän mielekkyyttä, kun tämä ei pysty edes ratsastamaan ilman apua:

Mun pikkuveli on yksi näistä kuolemalta pelastetuista. Sillä menee hyvin, ainoastaan raajat ja keuhkot ja puhekyky pielessä. Viime jouluksi laitoksesta lähetettiin kuva ratsastuspäivästä. Veli oli nostettu hevosen selkään, kaksi hoitajaa tuki sitä molemmin puolin ja yksi talutti heppaa suitsista. Pääsi mies kokemaan ratsastuksen hurmaa. (LVK, 38.)

Jiipee pyrkii oikeuttamaan toimintansa motiiveja kertomuksella veljestään. Jiipeen argumentit edustavat kantaa, jossa eläimiä voi hyödyntää ihmisen edun vuoksi: ihmisen

8 Ks. Luontoportti: Metsähanhi. 
hyvinvointi oikeuttaa eläimen kärsimyksen. Tällaisessa utilitaristisessa näkemyksessä eläinten käyttäminen ihmisten resursseina on moraalisesti hyväksyttävää, jos niitä kohdellaan "inhimillisesti" ja vältetään "turhaa" kärsimystä (Francione 2013, 113).

Lintu vai kala -näytelmässä kahden keskeisen henkilöhahmon ideologiat ja arvot törmäävät, mikä onkin tyypillistä aatedraamalle (Redling 2014). Ideologiat välittyvät etenkin eläinpuheiden välityksellä: niissä puhutaan eksplisiittisesti uhanalaisista eläimistä ja eläinten suojelusta, toisaalta taas eläinten käyttämisestä ihmisen hyvinvoinnin edistämiseksi. Metsähanhi nousee näytelmässä eläinsuojelun symboliksi, vaikka lintu jääkin passiiviseksi uhriksi aktiivisen toimijuuden sijaan (ks. Aaltola 2006, 89). Jos miettii ihmisen ja eläimen suhdetta tässä näytelmässä Kantolan (2014) jäsentelyn mukaan, niin ihminen, erityisesti Riikka päähenkilönä, toimii eläinten äänitorvena: saamme tietoa eläimistä ja niiden elinympäristöistä ja myös siitä, miten ihmisen toiminta on vaikuttanut eri lajien tilanteeseen. Ulkoisena kommunikaatiotilanteena näytelmä haastaa katsojaa pohtimaan eläimiin ja eläinten kohteluun liittyviä eettisiä ja poliittisia kysymyksiä Calarcon (2015) identiteettiteorioiden tapaan. Riikan äänellä kirjailija tuntuu sanovan, että ihminen on tehnyt luonnosta vihollisensa.

\section{3 \\ "Vesi, joka muutti ankeriaan naaraaksi, muutti Kristiinan."}

Kuningatar K:n dialogeissa vilisee erilaisia "limaisia" kaloja, kuten merikrotti, möhkökala ja ankerias, joka on keskeinen poissaoleva "eläinhahmo" sekä kielellinen motiivi ja symboli näytelmän kerronnassa. Kaikilla näytelmän henkilöillä on jonkinlainen suhde ankeriaaseen, ja se on vahvasti läsnä näytelmän dialogeissa. Näytelmä on fiktiivinen kuvaus 1600-luvulla eläneestä Ruotsin kuningatar Kristiinasta, ja sitä voisi luonnehtia leikitteleväksi tutkielmaksi sukupuolesta ja vallasta. Näytelmä on episodimainen, ja se etenee nopeasti Kristiinan syntymästä ja lapsuudesta aikuisuuteen. Jo lapsena poikatytöksi luonnehdittava Kristiina ihmettelee naisten toimintaa suhteessa miehiin. Myös historiankirjoituksissa kerrotaan, että Kristiinaa kasvatettiin kuin poikaa ja hänellä oli miesmäisiä piirteitä (Englund 2007, 59-61). Kun Kristiina löytää linnan kaivosta ankeriaan, siitä tulee hänelle pakkomielle: hän alkaa tutkia ankeriaan elämää kaloista kiinnostuneen kihlattunsa kreivi Karl Gustavin opastamana. Näytelmän rakenteessa on eeppisen draaman piirteitä, kuten esimerkiksi suoraa kerrontaa yleisölle. ${ }^{9}$ Koko näytelmä alkaa kohtauksella, joka on nimetty metaforisesti "Ankeriaiden hoviksi". Kohtaus rakentuu Kristiinan ja Karl Gustavin eläinmonologeista, jotka eivät varsinaisesti kytkeydy toisiinsa perinteisen vuoropuhelun tapaan.

KRISTIINA Jos ankeriailla olisi hovi, niin keskellä istuisi suuri naarasankerias ja pikkuiset urokset huojuisivat kuin vesiheinä valtaistuimen ympärillä. Mutta ne eivät olisi kuningattarelle kateellisia, sillä ne tietävät että jos ne uivat ylös jokiin

9 Kuningatar K:n kerrontaa on tutkinut Iiris Ylönen (2009). 
ja järviin, makeisiin vesiin, ne muuttuvat vähitellen itse naaraiksi, suuriksi ja painaviksi, ja saavat hallita, sulkea suureen syliinsä pieniä kapeita koirasherroja. Tarvitsee vain odottaa.

KARL GUSTAV En tiedä. Sen tiedän, että suuri musta ankerias, paksu kuin köysi, nostettiin yöllä kaivosta ja kuningatar katsoi sen hopeista vatsaa ja piiskaavaa pyrstöä, mutta ankerias katsoi kuningatarta silmiin ja sydämeen eikä hän sen jälkeen enää ollut sama. (KK, 179.)

Monologit kuvaavat vertauskuvallisesti näytelmän keskeisiä teemoja inhimillistetyn ankeriaan tarinan avulla. Niissä korostuu eläimen sukupuoli sekä kuningattaren rooli hallitsijana: näytelmä haastaakin pohtimaan sukupuolen ja vallan kompleksista kietoutumista. Myös Karl Gustavin mainitsema ankeriaan katse ja sen vaikutus Kristiinan muuttumiseen on tulkinnan kannalta merkityksellinen. Eläinpuheet liittyvätkin lähinnä sukupuoleen ja muuttumiseen, ei niinkään valtakysymyksiin. Monologit herättävät kysymyksiä näytelmän tulevasta sisällöstä sekä luovat tietynlaisen odotushorisontin näytelmän ei-realistisesta tyylistä.

Ankerias on monella tapaa "hieno kiinnostava ihmeellinen eläin" (KK, 188), kuten Kristiinakin toteaa tutkimustensa tuloksena. Esimerkiksi sen sukupuoli tarkentuu iän myötä, mihin aloitusmonologissakin viitataan. Näytelmän ankerias asuu linnan kaivossa. Ankeriaan kohtaaminen on käännekohta Kristiinan elämässä, sillä hän alkaa pohtia suhdettaan kihlattuunsa. Kohtauksessa 9, kun kihlapari tapaa kaivolla, Karl Gustav alkaa puhua Kristiinalle "miehen katseesta, jolla katsoo Kristiinaa" (KK, 192). Kristiina vastaa tälle kertomalla ankeriaan kohtaamisestaan:

Kun me menimme silloin yöllä yhdessä kaivolle ja ankerias nousi pintaan ja katsoi minua, niin minä ymmärsin, että jos osaisin - jos vain osaisin katsoa sinua samalla tavalla - minä sinua ja sinä minua - se olisi ensimmäinen kerta, kun mies ja nainen näkisivät toisensa niin kuin on tarkoitettu. Se katsoi minua niin kuin kaikkein ensimmäistä kertaa katsotaan, ensimmäistä kertaa, täynnä ihmetystä, uudesti, ilman himoa, vihaa, rakkautta, inhoa, hellyyttä tai omistamista, ilman mitään ennakkokäsitystä sellaisella katseella joka jättää meidät molemmat valloittamattomiksi ja vapaiksi. (KK, 193.)

Repliikin voisi tulkita niin, että Kristiina ei koe aitoa yhteyttä Karl Gustavin kanssa. Hän inhimillistää ankeriaan toiminnan, kun kertoo tämän katseesta ja kokemuksestaan: kohtaamisessa molemmat tunnistavat toisensa erityisyyden ja kunnioittavat sitä. Kristiinan kokemus vertautuu Jacques Derridan kuuluisaan kissan kohtaamisesimerkkiin, jossa Derrida kertoo, kuinka kissan katse on yllättänyt hänet, kun hän on ollut alasti ja hän alkaa pohtia nolostuneena, kuka hän on kohtaamishetkellä: eläin vai ihminen. Calarcon (2013) mukaan tällaisessa kohtaamisessa ihminen ikään kuin altistuu toiselle eläimelle ja "tulee itseensä ja saavuttaa itsetietoisuuden vain muissa eläimissä ja muiden eläinten kautta, toisin sanoen toisten elävien olentojen kautta, olivat ne sitten ihmisiä, eläimiä tai jotain 
muuta”. Kristiina, joka on lapsesta alkaen ollut hämmennyksissä sukupuolirooleista, löytää ankeriaasta selityksiä omalle toiminnalleen. Hän myös ymmärtää ankeriaan elämän omalaatuisuuden. Eläimiä koskeva eettinen ajattelu alkaakin juuri tällaisissa kohtaamisissa, jotka eivät ole aina rationaalisesti selitettävissä. (Calarco 2013, 173-178.) Kristiinan kuvausta voi pitää taiteen keinona kuvata toislajisen eläimen kohtaamista ilman kulttuurisia stereotypioita, jolloin huomio kiinnittyy eläinten erityisyyteen, ja täten mahdollistuu affektiivisen empatian herääminen (Aaltola 2015b, 306).

Kristiinalle ankeriaan kohtaaminen on merkityksellinen, sillä hän tiedostaa oman erityisyytensä ja alkaa pohtia sukupuolen merkitystä, omaa seksuaalisuuttaan ja tehtäväänsä valtakunnan kuningattarena. Kristiinan muuttuminen toiseksi toistuu usein henkilöhahmojen puheissa, kuten tämän alaluvun otsikossa siteeratussa Karl Gustavin repliikissä, jossa hän epäilee veden muuttaneen niin ankeriaan kuin Kristiinankin "toiseksi". Toiseksi muuttuminen onkin läpi näytelmän kulkeva teema. Kristiina on hämmentynyt tilanteestaan, ja hän kutsuu keskustelukumppanikseen tunnetun ranskalaisen filosofi René Descartesin, mikä on myös historiallisesti totta (esim. Englund 2007, 39). Historiallinen filosofi näki ihmisen ja eläimen kategorisesti erilaisina: eläimet ovat jumalan luomia koneita, joilla ei ole tuntoisuutta (Francione 2013, 114). Kristiinan käyttäytyminen laittaa myös Descartesin pohtimaan monologissaan sukupuolen muuttumisen problematiikkaa eläinesimerkkien avulla:

[M]inäkin mietin, koska en muuta voi, mietin että jos joku alkaisi muuttua naisesta mieheksi - niin kuin jotkut liskot muuttuvat vanhemmiten koiraiksi, tai tietynlainen ravinto muuttaa meritähden sukupuolen - niin milloin naaras lakkaa olemasta nainen ja sitä pitää kutsua mieheksi, mikä on se viimeinen hetki ja ehto ja edellytys? Ja mikä on se tila naiseuden ja miehuuden välissä? Mikä on se olento naiseuden ja miehuuden välissä? Onko se silloin molempia, sekä että vai ei kumpikaan? Vai ehkä jokin kolmas, uusi. Mutta kun nainen ei ole nainen vain silloin kun se synnyttää tai virkkaa tai imettää tai pesee pyykkiä, se naiseus on siinä kun se kävelee, syö, puhuu ja kaivaa nenäänsä. Jokainen joka Kristiinaa katsoo, näkee naisen, vaikka se kuinka ratsastaa ja lyö ja kiroaa miten kovaa tahansa. (KK, 188-189.)

Ruohonen on kirjoittanut filosofille kiinnostavaa pohdintaa sukupuolen olemuksesta ja mahdollisesta kolmannesta sukupuolesta. Descartesin pohdinnat ja Kristiinan toiminnat ja teot muistuttavat Judith Butlerin ajatuksia sukupuolen perfomatiivisuudesta. Butlerin (2006, 229-235) mukaan sukupuoli on rakennelma, joka koostuu ruumiin pintaan rakentuvista teoista, eleistä ja esityksistä, mutta se ei kuitenkaan paljasta henkilön todellista identiteettiä. Näytelmässä esiintyvä ankerias yhtäl̈ltä ikään kuin vahvistaa Kristiinan sukupuolen hämäryyttä, ja toisaalta "luonnollistaa" sen, sillä eläinmaailmassa sukupuolen muuttuminen on myös tunnettua. Iiris Ylönen $(2009,62)$ näkee ankeriaan sukupuolen muuttumisen symbolina. Näytelmän Kristiina-hahmon voisi hahmottaa transsukupuoliseksi, sillä hän kokee syntymässä määritellyn sukupuolensa ja siihen liittyvät fyysiset ja 
sosiaaliset piirteet itselleen vieraiksi. Descartes päätyy näytelmässä kuitenkin ajatukseen, että miesmäisestä käyttäytymisestään huolimatta Kristiina on sukupuoleltaan nainen. Kuvaavaa on, että hän näkee naiseuden vain ruumiillisten toimintojen kautta: nainen synnyttää, virkkaa, pesee, syö, kaivaa nenäänsä. Hän toteaakin Kristiinalle, että tämän tärkein tehtävä "on tuottaa kuninkaallisia jälkeläisiä" (KK, 190). Descartesin repliikeistä välittyy ajatus miesten ja naisten roolien epätasa-arvoisuudesta: hän ikään kuin rinnastaa naisen tuotantoeläimeen.

Kristiinan kiinnostus ankeriaaseen synnyttää yhteisössä pahennusta. Kautta aikojen eläimiin on liitetty monia stereotyyppisiä piirteitä, joita myös Ruohonen hyödyntää näytelmänsä dialogeissa. Tyypillistä on esimerkiksi eläinten ja eläimellisyyden yhdistäminen seksuaalisuuteen (esim. Simons 2002, 163). Karl Gustav kokee Kristiinan kuvauksen ankeriaan kohtaamisesta vaivaannuttavana. Hän liittää ankeriaan "likaiseen" seksuaalisuuteen ja toivoo, että Kristiina voisi mieluummin "kiinnostua vaikka muuttolintujen reiteistä, merikotkista" kuin limaisesta kalasta (KK, 193-194). Eri eläinlajien arvottaminen esimerkiksi niiden ulkonäön perusteella on tyypillistä ihmisille. Mitä enemmän eläin muistuttaa ihmistä, sitä helpompi meidän on kokea sen kanssa yhteisyyttä. Kategorisointi onkin perustavanlaatuinen retorinen strategia, jolla tuotetaan todellisuutta (Jokinen 2016, 341). Karl Gustav on jopa kateellinen ankeriaalle:

KARL GUSTAV Meinaatko mennä kalan kanssa naimisiin?

KRISTIINA Mitä?

KARL GUSTAV Minä en pidä siitä. Mitä se ankerias teki?

KRISTIINA Mitä? Tunnusteli.

KARL GUSTAV Mitä sinä teit?

KRISTIINA Samaa. Tunnustelin. Se kosketti minua.

KARL GUSTAV Niin? Entä sitten?

KRISTIINA (Ei vastaa)

KARL GUSTAV Mutta onko nyt sovittu, että me - onko sovittu, että me, sitten, kun tulen takaisin?

KRISTIINA Juu juu.

KARL GUSTAV Onko? Ettei mitään tapahdu sillä aikaa kun minä olen poissa? KRISTIINA Ei. Ei mitään. (KK, 193.)

Kristiinan näennäisen välinpitämätön kuvaus "inhimillisen" ankeriaan kohtaamisesta on eroottisesti latautunut tunnusteluineen ja koskettamisineen. Kristiinan voi yhtäältä tulkita kiusoittelevan kihlattuaan, josta hän haluaa päästä eroon, toisaalta hän voi kuvata vertauskuvallisesti kokemustaan ankeriaan kohtaamisessa. Karl Gustav on mustasukkainen ja huolissaan siitä, jos Kristiina pettää häntä "kalan kanssa". Ankerias muistuttaa muodoltaan käärmettä, johon se on usein vanhoissa tarinoissa yhdistetty. Muinaisissa kansojen luomistarinoissa käärme liittyi yhtäältä feminiiniseen hedelmällisyyskulttiin ja toisaalta myös maskuliiniseen fallossymboliin (Järvinen 1997, 116-117), joka voisi selittää Karl Gustavin huolta. 
Toinen eläimiin liitetty stereotypia juontaa juurensa Raamatun tulkinnoista. Esimerkiksi syntiinlankeemustarinassa seksuaalisuus, nainen ja käärme yhdistettiin pahuuteen ja ne olivat siksi halveksittavia. Eläimiä on sanottu paholaisen ruumiillistumiksi ja paholaisten apureiksi, ja niiden ilmentymiä ovat olleet esimerkiksi pukki, käärme, lepakko ja sammakko. (Aaltola 2004, 25; Järvinen 1997, 117.) Kristiinan äiti antaa ymmärtää, että Kristiinan kiinnostus ankeriaaseen liittyy noituuteen ja kasvavaan syntiin, kun "naiset naamioituvat käärmeiksi, vesikäärmeiksi, ankeriaiksi, luikertelevat sieluun ja jäävät sinne syvyyden pohjalle asumaan, mustaan veteen ja kasvavat siellä hiljaisuudessa yhä suuremmiksi." (KK, 207.) Hän kertoo myös tarinan lapsensa murhasta epäillystä naisesta, jonka "sänkyyn oli ryöminyt käärme, jonka kanssa se oli paritellut" (KK, 208). "Kuningattaren käärme" saa yliluonnolliset mittasuhteet kyläläisten puheissa, kun sen kerrotaan "kietoutuneen jonkun jalan ympärille" ja "sylkeneen punaista sappea" ja sitten kadonneen säkistä $(K K, 204)$. Stereotyyppiset kulttuuriset käsitykset eri eläimistä vaikuttavat tänä päivänäkin eläinten kohteluun.

Ruohonen purkaa näytelmässään näitä käsityksiä eläimistä käyttämällä eläinpuheissa luonnontieteellistä tietoa. Hän toteaakin näytelmän jälkisanoissa, että tiedot ankeriaasta, merikrotista ja möhkökalasta pitävät paikkansa (Ruohonen 2004, 224). Esimerkiksi ankeriaasta saamme tietää, että se laskee neljä miljoonaa munaa kerrallaan (KK, 190). Ennen vanhaan se on ollut arvokas talouskala, kuten Karl Gustav toteaa: "Ankeriashan on toki kansantaloudellisesti yksi tärkeimpiä kalojamme, en sitä väheksy, mutta ei myöskään enempää eikä vähempää, riittää kun sitä on ja saa savustettuna lautaselle.” (KK, 194.) Kristiina on innoissaan ankeriaasta ja sen taidoista:

Kuuntele! KG sanoi, että ankerias voi nousta kuivalle maalle ja vaeltaa pitkiä matkoja ja löytää aina vettä, vaikka olisi myrsky ja pilkkopimeä. Autiomaasta se löytää lähteet ja pelastaa ihmisiä kuolemasta janoon. Ja se voi olla neljä vuotta syömättä! Neljä! Ajattele. Ankeriasnaaraat elää järvissä ja joissa kaikessa rauhassa kymmenen vuotta tai - tämä on ennätys - jopa kolmekymmentäkahdeksan vuotta, mutta lopulta ne jättävät vanhan elämänsä ja lähtevät vaeltamaan kohti Sargassomerta, ja kuuntele, ajattele - siellä kuuden kilometrin syvyydessä vietetään niiden salaiset häämenot, joita kukaan koskaan ei ole päässyt näkemään. (KK, 187.)

Ankerias on mystinen kala, sillä esimerkiksi sen lisääntymisestä ei tiedetä paljoa. Oletetaan, että ankeriaat menevät kutemaan Sargassomerelle, mihin myös näytelmän dialogissa viitataan. Pienet toukat ajautuvat Golf-virran mukana Eurooppaan, jossa ne kasvavat niin sanotuiksi lasiankeriaiksi. Nämä hakeutuvat jokia pitkin sisävesiin ja alkavat muuttua sellaisiksi ankeriaiksi, joita me tunnemme. Kalan sukupuoli tarkentuu iän myötä. Se voi elää vanhaksi ja liikkua myös kuivalla maalla. Nykyään ankerias on luokiteltu uhanalaiseksi lajiksi. ${ }^{10}$ Näytelmässä viitataan myös muihin kaloihin. Karl Gustav, joka on kiinnostunut erilaisista kaloista, pohtii monologissaan kalojen monimuotoisuutta verrattuna ihmiseen:

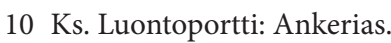


[J]a kaloissa on vaihtelua, ihmiset ovat kaikki samanlaisia, miehet ja naiset, elävät ja kuolleet, mutta kaloilla voi olla kaksi suuta ja ruumis vyötärön kohdalta poikki. Ne voi olla kynttä pienempiä tai niin isoja, että jos niihin törmää menee veneestä pohja puhki. Ja maailman rumin olento on kala, merikrotti, siis naaraspuolinen, iho on yhtä syylää ja ryhelmää, oikea pirunnaama. Kun se haluaa paritella, se houkuttelee uroksen paikalle erittämällä sellaista kemikaalia, että sulhanen alkaa kutistua ja menettää näkö- ja hajuaistinsa. Vähitellen uros surkastuu pelkäksi siittiöpussiksi ja sulautuu osaksi naarasta, se on enää jonkinlainen pikkuinen loiseläin naaraan peräaukon vieressä ja elää niillä muruilla, joita naaraan suusta putoilee. $(\mathrm{KK}, 186$.

Usein eläimet, kuten kalat, nähdään yhtenä ryhmänä, samanlaisina olioina, vaikka niissä on erilaisuutta enemmän kuin ihmisissä. Eläinfilosofian erilaisuus-teoriat näkevätkin erilaisuuden korostamisen tärkeänä lähtökohtana. Eläimistä, saatikka lajeista, ei voi puhua yhtenäisenä ryhmänä, sillä lajin sisälläkin on yksilöllisiä eroja (Calarco 2015, 37). Karl Gustavin monologi viittaa myös näytelmän sukupuolitematiikkaan, kun siinä kuvataan merikrotin erikoista "parisuhdetta". Hän kertoo myöhemmin myös möhkökalasta, jolla on erityinen kyky: "Se on vaan tyypillinen maallikon harhaluulo, että kaikki kalat olisivat mykkiä, eivätkä ole, esimerkiksi möhkökala, kun sen vetää pintaan, se mölisee, se mölisee, huutaa niin kuin lehmä." (KK, 198.) Nykyinen eläintutkimus onkin tuonut esille erilaisten eläinten monipuolisia kykyjä, joita on pidetty vain ihmiselle ominaisina (Aaltola 2013, 13).

Näytelmän loppupuolella Kristiina käy kaivossa ja hän huomaa, että ankerias on kadonnut. Pian tämän tapahtuman jälkeen myös kaivo tukitaan, ja Kristiina päättää luopua vallasta ja lähteä Roomaan paavin luo. Näytelmän viimeisessä repliikissään, joka assosioituu Jeesuksen viimeiseen ateriaan ja ehtoolliseen (Ylönen 2009, 67-68), Kristiina analysoi omaa tilannettaan - ikään kuin etäännytettynä:

Paavin pöydässä, ei voi kysyä, ei kieltäytyä, ei ajatella, syödä vain, syödä se ateria joka on eteen vitilumenvalkealle liinalle katettu, juoda verenpunaista viiniä ja katsoa yli ihmismeren joka suurin silmin, silmää räpäyttämättä katsoo kuinka suu jauhaa ja kristallipikari nousee huulille. Kuinka entinen kuningatar söi ja nieli paavin aterian ja ankeriaan liha muuttui hänen lihakseen ja yhtyi häneen lihaansa, muuttui hänen hiuksikseen ja ihokseen ja ajatuksikseen koskaan enää sieltä lähtemättä. $(K K, 217$.

Näytelmän loppua voi tulkita monella tavalla. Ylönen pohtii, että loppu voisi olla Kristiinan kannalta onnellinen, sillä hän vapautuu menneestä ja aloittaa uuden elämän. Toisaalta hän miettii, pakeneeko Kristiina uutta kestämätöntä tilannettaan "sulautumalla" eläimen muotoon. (Ylönen 2009, 67-69.) Yksi tulkinta voisi olla se, että Kristiina on sinut itsensä kanssa, ja hän on sisäisesti sitä, mitä hän haluaa olla. Repliikin alku kieltoineen "ei voi kysyä, kieltäytyä, ajatella" viittaa kuitenkin siihen, että Kristiinan oma ajattelu on vaiennettu. Kenties hänen täytyy piilottaa oma eläimellisyytensä ja todellinen sukupuolensa? 
Kuningatar K:ssa eläinpuheiden perusteella ihmisen ja eläimen suhteen esittämisen voi tulkita kaksisuuntaisena: ihminen saa eläimen ominaisuuksia ja eläin inhimillisiä piirteitä (vrt. Kantola 2014). Ankeriaan ja ihmisen yhteys korostaa samankaltaisuutta: ihminen on eläin ja osa luontoa. Kristiina löytää itsensä ankeriaan kohtaamisessa: hän ikään kuin tulee omanlaiseksi eläimeksi. Näytelmä haastaa katsojaa pohtimaan sukupuolen monimuotoisuutta niin eläin- kuin ihmisten maailmassa. Eläin on näytelmässä aktiivinen toimija, ja näin se purkaa ihmiskeskeistä näkökulmaa (ks. Calarco 2015). Ihminen toimii myös eläimen äänitorvena, sillä eläinpuheissa on paljon luonnontieteellistä tietoa erikoisista ja omalaatuisista eläimistä, niiden käyttäytymisestä sekä monipuolisista kyvyistä ja taidoista, jotka osaltaan purkavat eläimiin liitettyjä stereotypioita. Kuningatar $K$ :ssa eläinpuheet herättävät tunteita sekä näytelmän sisäisessä että ulkoisessa kommunikaatiotilanteessa. Näytelmässä on käytetty myös aatedraamassa tyypillistä keinoa eli henkilöhahmona esiintyvää filosofia (esim. Puchner 2010).

\section{4 "Voi! Lepakko on melkein kuin ihminen."}

Luolasto-näytelmässä on kaksi keskeistä eläinlajia, lepakko ja olmi ${ }^{11}$, jotka toistuvat eläinpuheissa ja osittain esiintyvät myös fyysisinä hahmoina. Eläimet ovat osa luolien ekosysteemiä, jota ihminen on tuhoamassa luoliin sijoitettavalla ydinjätteellä. Jos Lintu vai kala -näytelmässä huoli liittyy joidenkin eläinlajien kuolemiseen sukupuuttoon, on tämän näytelmän mittakaava toinen. Luolaston voi hahmottaa analogiana maapallolle, jonka elämän ihminen on tuhoamassa omalla toiminnallaan. Näytelmän voikin hahmottaa dystooppisena tulevaisuuden kuvana. Luolien rakenteita ja rakenteisiin liittyviä ongelmia on selvittelemässä insinöörikolmikko, jonka tutkimuksia häiritsee ikivanhoja luolamaalauksia tutkimaan tullut "naiseksi" nimetty arkeologi. Luolissa asuu myös entisiksi nimettyjä "haamuja", muinaisten ihmisten ääniä, jotka varoittavat tulevasta tuhosta. Luolat eivät kestä ihmisen toimia, ja ne alkavat romahdella näytelmän lopussa. Vaikka näytelmän aihe on vakava, on siinä paljon satiirisia piirteitä. Näytelmän henkilökuvaus on tyypittelevää, ja sen dramaturgiaa luonnehtivat episodimaisuus, runomuotoisuus ja eri genrejen sekoittuminen. (Lintunen 2017, 174, 185.)

Näytelmässä eläinten "äänitorvina" toimivat insinööriharjoittelija Asko sekä arkeologinainen, joiden dialogit ja toiminta haastavat pohtimaan ihmisen ja eläimen samanlaisuutta ja erilaisuutta. Asko on erittäin innostunut lepakoista, ja hän on kehitellyt laitetta, Askofonia, jonka avulla pystyisi ymmärtämään lepakkoja. Monologissaan hän pohtii kriittisesti lepakkojen ja ihmisen suhdetta:

Lepakot kuulee kaiken, mitä ihminen sanoo, mutta ihminen ei tajua sanaakaan siitä, mistä lepakot ovat puhuneet keskenään viimeiset miljoona

11 Ks. Wikipedia: Olmi. 
vuotta. Se on todella hälyttävää! Siinä ajassa on väistämättä sanottu jotain todella tärkeää! Mutta ihminen elää kuin pää pussissa, ei näe ei kuule eikä tajua puoliakaan siitä, mikä on kaikille muille lajeille päivänselvää. Ihmistä käy sääli. Sitä pitää auttaa.

Sen takia on olemassa insinöörejä.

Me keksimme laitteen, joka kertoo kuurosokealle, että ovikello soi ja vesi kiehuu, ja tämän Askofonin avulla ihminen saa tietää, miksi lepakko opetteli lentämään, vaikka on nisäkäs ja miten hitossa yhteiskunnan voi pitää kasassa puolimiljardia vuotta ilman ainuttakaan sotaa? Kaikkeni teen, että ihmisestä tulee taas osa luomakuntaa. (L, 31.)

Askon monologi kertoo hänen kiinnostuksestaan luontoa kohtaan, halusta ymmärtää eläimiä ja saada ihmiset käsittämään olevansa osa "luomakuntaa" ja yksi laji muiden joukossa. Hän päätyy ihmistä ja lepakkoa vertaillessaan oivallukseen, että "Lepakko on melkein kuin ihminen. Molemmat ovat aina saaneet kärsiä erilaisuudestaan." (L, 32.) Myös arkeologinainen viittaa ihmisen ja eläimen samanlaisuuteen, kun hän sanoo olmia kutsuttavan "luolien ihmiseksi" (L, 42). Katri Tanskanen $(2017,23)$ sanookin ihmisen näyttäytyvän Luolastossa, kuten muissakin Ruohosen näytelmissä, olentona, joka on unohtanut olevansa eläin muiden joukossa. Identiteetti-teorioissa onkin tyypillistä, että eläintä verrataan ihmiseen ja että ihmisen ja eläinten erot nähdään aste-eroina: emme ole täysin samanlaisia, mutta eri lajeilta löytyy samanlaisia piirteitä ja kykyjä (Calarco 2015, 11-13). Askon mainitsema lepakon erilaisuus liittynee siihen, että se on ainoa lentävä nisäkäs, ja siihen on yhdistetty monia pelottavia ja aikojen kuluessa syntyneitä stereotyyppisiä piirteitä ja uskomuksia. Näytelmässä viitataan esimerkiksi vesikauhuun, jota lepakoiden sanotaan levittävän: "Tarttunut lepakosta. Kaikki oireet täsmää: käytös ja mieliala heittelee kuin hullun muna." (L, 20.) Lepakkoja on pidetty mustina enkeleinä, paholaisen sukulaisina, kummitusten kumppaneina, noidan sielun kantajina ja kuoleman sanansaattajina. Lepakot yhdistyvät mielikuvissa myös vampyyreihin. (Lappalainen 2003, 139-148.) Lepakot kantavat ihmisten mielissä samanlaista stigmaa kuin Kuningatar K:ssa esiintyvä ankerias. Askon mainitseman ihmisen erilaisuuden voisi yhdistää myös ihmisen tietoiseen vieraantumiseen muista eläimistä ja luonnosta. Aaltola $(2013,12)$ toteaakin, että ihminen on historian kuluessa halunnut erottautua eläimistä ja olla erityinen ja täydellisempi kuin eläimet.

Ihmisen halu näyttäytyä parempana kuin eläimet näkyy muun muassa eläinvertauksissa, joissa ihmistä arvotetaan suhteessa johonkin eläimeen. Eläinmetaforat ovat syntyneet aikojen kuluessa, ja erityisen suosittuja ovat olleet kotieläimiin liittyvät vertauskuvat, joiden kautta puhuja kertoo jotakin omista tunteistaan, asenteistaan ja suhtautumisestaan puheena olevaan asiaan (Häkkinen 2002, 49-50). Luolastossa syntyy huvittava tilanne, kun luolia vartioiva mies, joka on rakastunut arkeologinaiseen, kysyy, minkä eläimen tämä haluaisi ottaa lemmiksi. Nainen kertoo, että jos olisi pakko, hän ottaisi olmin. Mies ihmettelee: 
MIES Olmin!? Se aneeminen, sokea pötkylä? Mutta mitä se kertoo meidän suhteestamme...

\section{NAINEN Mitä?}

MIES (joutuu paniikkiin) meidän suhteestamme... eläimiin... jos oletetaan että olet ihminen... niin kuin tietysti oletkin... niin ihmisen suhde eläimiin kertoo sen suhteesta ihmiseen... läheiseen ihmiseen... tai siis lähimmäiseen... lähimmäistyyppiseen... - -

NAINEN No...ennen kyllä luultiin että olmi elää ikuisesti, mutta kun sitä ruvettiin tutkimaan, paljastuikin, ettei se oikeasti eläkään pitkään vaan pelkästään hirvittävän hitaasti. On niin kylmää ja pimeää että mitään ei tapahdu. Ikinä! $(\mathrm{L}, 36-37$.

Mies hämmentyy, kun nainen valitsee aneemisen ja sokean olmin jonkun "sopivamman" eläimen sijaan. Tämä kertoo tyypillisesti myös siitä, miten arvotamme erilaisia eläimiä esimerkiksi niiden ulkonäön tai elintavan perusteella. Toisaalta tämä dialoginpätkä valottaa humoristisesti tapaamme verrata itseämme ja toisiamme eläimiin. Myös nainen vertaa olmin elämää ihmisen elämään ja arvottaa sen "tylsäksi", kun mitään ei koskaan tapahdu. Myöhemmin hän luonnehtii monologissaan olmia yhtä avuttomaksi ja paljaaksi kuin ihmistä, ja joka "värisee himosta, elää ja kuolee. / Kuinka pieniltä näyttävät sen tunteet / kuinka merkityksettömiltä pyrkimykset. / Ei ihme, että sitä kutsutaan luolien ihmiseksi." (L, 42.) Naisen voisi tulkita puhuvan ironisesti myös omasta elämästään, josta puuttuu rakkautta.

Naisen elämä saa kuitenkin uuden suunnan, kun hän löytää luolan, jossa on mystinen maanalainen järvi ja jota parenteesissa kuvataan "ikivanhaksi uhripaikaksi" (L, 82). Luolassa hän kuulee muinaisten ihmisten äänet, ja hän muuttuu lepakoksi." (L, 83.) Kun nainen palautuu "ennalleen", hän sanoo: "Olla osa maailmaa, kuulua siihen joka säikeellään, eikä kävellä sen pinnalla kuin muukalainen." (L, 83.) Hän on ikään kuin oppinut jotain tärkeää ihmisen ja luonnon yhteydestä. Repliikin voi tulkita kirjailijan viestinä siitä, miten tärkeää on, että ihminen kokee olevansa ja on osa luontoa. Simons $(2002,142)$ kirjoittaakin, että muodonmuutos vahvistaa inhimillisen ja ei-inhimillisen yhteyttä. Lepakoksi muuttuminen tuo näytelmään fantasian piirteitä. Muuttumista voisi tulkita myös Gilles Deleuzen ja Félix Guattarin eläimeksi-tulemisen käsitteen avulla. Eläimeksi-tuleminen hävittää ihmisen ja muiden eläinten välistä dualistista ajattelua, ja se mahdollistaa hyppäämisen kohti eläimellisyyttä, erilaista tapaa olla. He puhuvat niin sanotuista "häirikköeläimistä", jotka rikkovat eläimille annetun alisteisen aseman ja tuovat eläimellisen toimijuutensa esille. Eläinten tapa jäsentää todellisuutta voi avata ihmisten silmiä uudenlaiseen jäsennykseen. (Aaltola 2013, 282-283.) Näytelmän naisen voi sanoa ymmärtäneen eläimenä ollessaan jotain uutta, sillä dystooppinen näytelmä päättyy toiveikkaaseen kuvaan naisen lähtiessä viemään valoa pimeyteen.

Luolaston eläinpuheissa korostuu myös kritiikki ihmisen toimintaa kohtaan. Askon sanojen mukaan "ihminen elää kuin pää pussissa" eikä ymmärrä sitä, "mikä kaikille muille lajeille on päivänselvää" (L, 31). Lepakoiden sopuisa sosiaalinen elämä, johon 
eivät kuulu esimerkiksi sodat, saa kiitosta sekä Askolta että Myyrä-nimiseltä insinööriltä, joka toteaa: "Kaksi miljoonaa elukkaa elää hyvässä järjestyksessä ja jokainen hoitaa hommansa. Kukaan ei ole toisen yläpuolella" (L, 71). Yksi kiinnostava ihmisen toimintaan liittyvä kritiikki liittyy eläinten käyttämiseen ravintona. Myyrä tappaa vahingossa olmin, ja myöhemmin hän grillaa sen syötäväksi, mistä seuraa koominen episodi eläinkeskusteluineen. Olmin raatoa kohdellaan kuin "siskonmakkaraa", mutta epäily eläimen myrkyllisyydestä tai pyhyydestä saa Myyrän lopettamaan syömisen. Olmi muistuttaa ihmisen sikiötä, ja siksi "luolien ihmisen" syöminen on groteski yksityiskohta satiirisessa näytelmässä. Pieni episodi viittaa yleensäkin eläinten käyttämiseen ravintona ja sen oikeutukseen. Olmin voisi nähdä edustavan harvinaisia eläimiä, joita edelleenkin käytetään gourmetruokana esimerkiksi etnisissä keittiöissä.

Asko uskoo, että hän pystyy keksintönsä, Askofonin, avulla ymmärtämään lepakoita. Vaikka Askolla on hyvä tarkoitus, voi tämän pyrkimyksen nähdä ironisoivan ihmisen kaikkivoipaa uskoa, että luontoa voi hallita ja ymmärtää tekniikan avulla. Koko näytelmän mittakaavassa insinöörit eivät pysty hallitsemaan luolia millään tekniikalla, vaan luolat alkavat romahdella, jolloin myös luolien ekosysteemi on uhattuna. Näytelmässä luolat rinnastuvat maapalloon, ja kun "maapallo falskaa" insinöörien sanoin (L, 96), uhkaa ydinjätteen leviäminen kaikkea elollista. Luolasto luokin apokalyptisiä kuvia ihmisen toiminnan seurauksista. Viime aikoina on puhuttu "kuudennesta sukupuutosta". Eri alojen tutkijat ympäri maailmaa varoittivat syksyllä 2017 yleisten lajien vähenemisen vaikuttavan ekosysteemiin eniten, mikä aiheuttaa vakavia ekologisia, taloudellisia ja yhteiskunnallisia seurauksia (Mikkonen 2017). Myös ihminen itsekin on uhattuna, kuten näytelmän entiset ennustavat runomuotoisessa monologissaan:

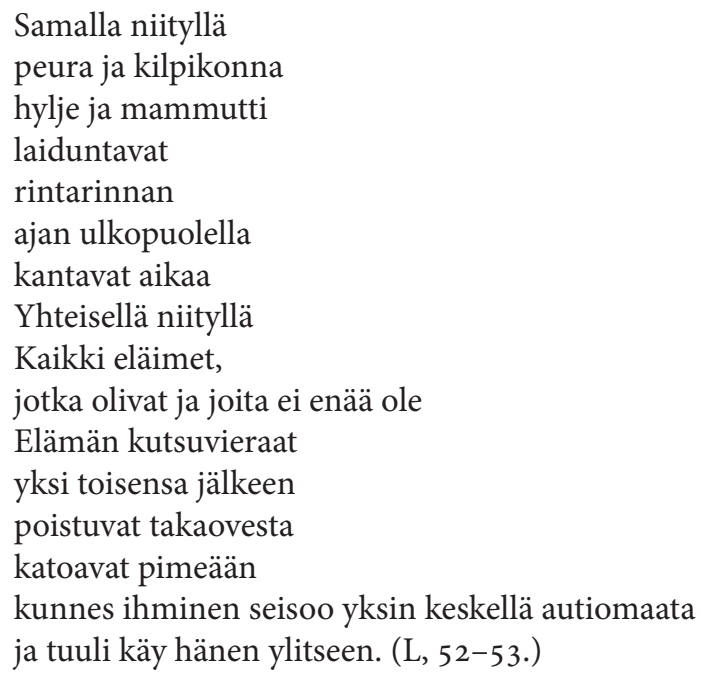

Eläimiin liittyvät kielikuvat luovat tehokkaita ja tunteisiin vetoavia visioita tulevasta tuhosta, kuten "ajan ulkopuolella laiduntavat eläimet", "eläimet, joita ei enää ole", ja "elämän 
kutsuvieraat, jotka poistuvat takaovesta". Lopulta myös ihminen tuhoutuu ja "tuuli käy hänen ylitseen". Runomuoto luo näytelmään myös tietynlaista kohtalonomaisuutta, ja synnyttää myös alluusion antiikin tragedioihin. Entisten "runossa" korostuu myös aikaperspektiivi: eläimiä on ollut jo ennen ihmistä, toisaalta aikojen kuluessa ihmisen toimet ovat ajaneet jotkut eläinlajit sukupuuttoon.

Tanskanen $(2017,92)$ luonnehtii Luolastoa ekodramaturgiseksi teokseksi, koska se käsittelee ihmisen suhdetta muihin lajeihin ja ekosysteemiin. Näytelmä luo uhkaavan ja tunteita herättävän skenaarion tulevaisuudesta, jos ihminen ei muuta toimintaansa. Teos on kirjoitettu ajankohtana, jolloin oltiin päättämässä uusista ydinvoimaloista ja toisaalta miettimässä ydinjätteen loppusijoitusmahdollisuuksia. (Lintunen 2017, 185.) Näytelmässä ihminen toimii Kantolan (2014) jäsentelyn mukaan eläimen äänitorvena, toisaalta voi ajatella, että eläimet edustavat myös itseään fyysisinä aktiivisina toimijoina. Nainen saa eläimen ominaisuuksia muuttuessaan lepakoksi: eläimeksi-tuleminen ikään kuin laajentaa hänen ymmärrystään ympäristöstä ja luolien tilanteesta. Tämä purkaa myös ihmiskeskeistä näkökulmaa (ks. Calarco 2015). Yhtäältä näytelmän eläinpuheet korostavat ihmisen ja eläinten samankaltaisuutta, ja toisaalta eläinpuheiden kautta kritisoidaan ihmisen toimintaa. Tässä näytelmässä eläinten kohtalo on sidottu luolien tilanteeseen: kun luolat alkavat hajota, ovat eläimet ja koko luolien ekosysteemi vaarassa. Kun Lintu vai kala -näytelmässä ihmisen toiminta uhkaa vain eläimiä ja luontoa, on Luolastossa vaarassa koko maapallon eläimistö ihminen mukaan luettuna.

\section{Lopuksi: Olla osa maailmaa}

Tässä artikkelissa olen tutkinut Ruohosen näytelmien eläimiin liittyviä dialogeja ja monologeja osana aatedraaman rakentumista. Ruohonen haastaa katsojaa pohtimaan laajemminkin ihmisen ja luonnon problemaattista suhdetta, ja tässä eläimiin liittyvä retoriikka avaa yhden näkökulman. Eläimet ovat näytelmissä vahvasti läsnä muistuttamassa läsnäolostaan yhteisessä maailmassamme. Esimerkiksi Karoliina Lummaa näkee lintujen representaation runoudessa lintujen edustamisena (Lummaa 2013b, 96), ja tätä voi pitää myös poliittisena kannanottona eläinten puolesta. Kaikissa Ruohosen näytelmissä ihmisen ja eläimen välille syntyy jännite, joka tuo mukanaan poliittisen ulottuvuuden, varsinkin kun ihmisen toimintaa kritisoidaan (ks. Tähtinen 2012).

Olen analysoinut Ruohosen kolmea näytelmää eri vuosikymmeniltä. Näytelmien eläinpuheet painottuvat kussakin hiukan eri tavalla, vaikka myös yhteisiä piirteitä löytyy, kuten esimerkiksi luonnontieteellisen tiedon käyttäminen. Näytelmät heijastavat kirjoittamisajankohtansa luonto- ja eläinkäsityksiä. Lintu vai kala on kirjoitettu 1990-luvun alussa, jolloin huoli eläinten ja luonnon tilasta oli jo kaikkien tietoisuudessa, vaikka aihetta ei oltu juurikaan käsitelty esimerkiksi draamakirjallisuudessa. Eläinfilosofian näkökulmasta Lintu vai kala -näytelmässä korostuu eläinten suojeluun ja hyötykäyttöön liittyvät eettiset kysymykset, vaikka eläimet jäävätkin passiiviseen rooliin. Näytelmän suorasukainen sävy viittaa perinteisempään aatedraamaan (ks. Hosiaisluoma 2016). 
Kuningatar K:ssa näkyy puolestaan 2000-luvun alun konteksti, jolloin sukupuolentutkimus oli saanut jalansijaa, ja esimerkiksi Judith Butlerin ajatukset sukupuolen performatiivisuudesta olivat tulleet Suomessa tutuiksi. Näytelmän eläinpuheet haastavat pohtimaan ihmisen ja eläimen samankaltaisuutta ja toisaalta myös erityisyyttä sekä sukupuolen monimuotoisuuden kysymyksiä. Eläin näyttäytyy aktiivisena toimijana ihmisen kohtaamisessa ja saa aikaan muutoksen. Ankeriaan lisäksi Kuningatar K:ssa on myös muita erikoisia eläimiä, joiden kyvyistä saamme tietää eläinpuheissa. Näytelmästä on tulkittavissa posthumanistisia painotuksia, kun se kyseenalaistaa ihmisen erityisasemaa ja korostaa ei-inhimillisen merkitystä (ks. Tanskanen 2017, 95). Kuningatar K, samoin kuin Luolasto, edustavat enemmän Redlingin (2014) esille tuomaa aatedraaman nykysuuntausta, joka herättää enemmän kysymyksiä kuin antaa valmiita vastauksia.

Myös Luolastosta (2014) voi tulkita posthumanistia piirteitä. Siinä esiintyy erikoisia eläimiä eli lepakkoja ja olmi, jotka ovat todellisuudessa uhanalaisia kuten ankeriaskin. Eläinten elinympäristö on uhattuna, kun luoliin ollaan sijoittamassa ydinjätettä. Ydinvoimaloiden lisärakentaminen ja ydinjätteen loppusijoittelu ovat olleet kuumia poliittisia kysymyksiä viime vuosina. Eläinpuheissa korostuu ihmisen ja eläimen samankaltaisuus, ja toisaalta se, että ihminen unohtaa olevansa eläin toisten joukossa. Näytelmässä vihjataan mahdolliseen eläinten ja ihmisen sukupuuttoon, jollei ihminen muuta toimiaan. Näytelmän päähenkilöksi luonnehdittava nainen muuttuu välillä eläimeksi, ja ikään kuin näin oivaltaa, että asioiden huonolle tilalle voisi tehdä jotain. Ruohonen korostaa eläinten näkökulmaa, sillä se voi avata uusia toimintamalleja ongelmatilanteisiin.

Aatedraaman kannalta näytelmien eläinpuheet ja eläinten toiminta tuovat ihmisen ja luonnon suhteen tarkasteluun erilaisia eläinfilosofisia ulottuvuuksia. Kussakin näytelmässä eläinpuheet herättävät affektiivista empatiaa, toisaalta näytelmissä on luonnontieteellistä eläintietoutta (ks. esim. Lummaa 2013b), joka haastaa myös reflektoimaan omia eläinkäsityksiään ja uskomuksiaan eli herättää Aaltolan esittämää reflektiivistä empatiaa. Dialogin funktioista appellatiivinen ja referentiaalinen korostuvatkin eläinpuheissa. Jos Ruohosen näytelmiä peilaa Malamudin (2009) eläinten esittämisen esteettisiin tavoitteisiin, niin tavoitteet toteutuvat suurelta osin: eläimet esitetään omassa ympäristössään eläintä kunnioittaen ja myös eläintietoutta lisäten. Ruohonen tuntuu painottavan, että ihminen on yksi eläin muiden joukossa. Toisaalta ihmisellä on myös suuri vastuu muista eläimistä ja elämän jatkumisesta maapallollamme. Eläinten ja muiden ei-inhimillisten käyttäminen näytelmissä kuvastaa Ruohosen ideologiaa: "Olla osa maailmaa, kuulua siihen joka säikeellään, eikä kävellä sen pinnalla kuin muukalainen", kuten Luolasto-näytelmän (2014) nainen toteaa. 


\section{Lähteet}

\section{Aineslähteet}

RuOHOnen, LAura 2005 (1992): Lintu vai kala. Lasipalatsi, Helsinki.

2004 (2003): Kuningatar K [= KK]. Teoksessa Kuningatar K ja muita näytelmiä 2004. Otava, Helsinki.

2014: Luolasto [= L]. ntamo, Helsinki.

\section{Kirjallisuus}

Aaltola, ElisA 2004: Eläinten moraalinen arvo. Vastapaino, Tampere.

— 2006: Eläinetiikka teoriasta käytäntöön. Niin \& näin: filosofinen aikakauslehti 13 (3): 83-91. 2013a: Johdanto: Ihminen, eläin vai molemmat? Elisa AALTolA (toim.): Johdatus eläinfilosofiaan, 9-27. Gaudeamus, Helsinki.

2013b: Lopuksi: Kohti eläintä. ElisA AAltola (toim.): Johdatus eläinfilosofiaan, 279-289. Gaudeamus, Helsinki.

2015a: Eläimellinen moraalipsykologia: tunne, järki ja kiasmat. Niin \& näin: filosofinen aikakauslehti (2): 91-98.

2015b: Tappava rakkaus: Itsepetos, empatia ja tarkkaavaisuus. Elisa Aaltola ja SAmi Keto (toim.) Eläimet yhteiskunnassa, 285-310. Into, Helsinki.

Ahola, Suvi 2014: Teatteriohjaaja Laura Ruohonen ottaa riskejä - ja tarvittaessa turpiin. Helsingin Sanomat, 8.3.

Butler, Judith 2006: Hankala sukupuoli: Feminismi ja identiteetin kumous. Gaudeamus, Helsinki.

Calarco, Matthew 2013: Derrida - eläimen kiihko. Elisa Aaltola (toim.): Johdatus eläinfilosofiaan, 152-178. Gaudeamus, Helsinki.

2015: Thinking through animals: Identity, difference, indistinction. Stanford University Press, Stanford California.

Englund, Peter 2007: Kuningatar Kristiina: Elämäkerta. WSOY, Helsinki.

Francione, Gary L. 2013: Eläinsuojelu ja eläinten moraalinen asema. Elisa Aaltola (toim.): Johdatus eläinfilosofiaan, 113-128. Gaudeamus, Helsinki.

GARRARD, GREg 2012: Ecocriticism. Routledge, London.

HAIlA, YRJÖ - LÄHDE, VIlle 2003: Luonnon poliittisuus: Mikä on uutta? YRJÖ HaIla ja VILlE LÄHDE (toim.): Luonnon politiikka, 7-36. Vastapaino, Tampere.

Häkkinen, Kaisa 2002: Eläin suomen kielessä. Henni Ilomäki ja Outi Lauhakangas (toim.): Eläin ihmisen mielenmaisemassa, 26-62. SKS, Helsinki.

Hosiaisluoma, Yrjö 2016: Kirjallisuusoppi: Aapisesta äänirunoon. Avain, Helsinki.

Järvinen, Antero 1997: Käärme. Jumalattaresta paholaiseksi: käärmeen ja ihmisen tarina. Kirjayhtymä, Helsinki.

Jokinen, ArJa 2016: Vakuuttelevan ja suostuttelevan retoriikan analysoiminen. ArJa Jokinen, KIRSI Juhila ja Eero Suoninen (toim.): Diskurssianalyysi. Teoriat, peruskäsitteet ja käyttö, 337-368. Vastapaino, Tampere.

KANTOLA, JANNA 2014: Eläimet Veikko Huovisen tuotannossa. Luokittelusta eläinsuhteen ilmenemiseen. Joutsen: Kotimaisen kirjallisuudentutkimuksen vuosikirja: 110. Saatavissa https://jyu.finna. fi/Record/arto.1602639.

Karlshuker: bird-eating deer and flesh-eating sheep. Saatavissa http://karlshuker.blogspot.com/2014/02/ bird-eating-deer-and-flesh-eating-sheep.html. [Viitattu 14.2.2018.]

LAhtinen, TONi - LeHTimäKi, MARKKU 2008: Johdatus ekokriittiseen kirjallisuudentutkimukseen. Toni Lahtinen ja Markкu Lehtimäкi (toim.): Äänekäs kevät. Ekokriittinen kirjallisuudentutkimus, 7-28. SKS, Helsinki.

LAPPALAINEN, MARKKU 2002: Lepakot: Salaperäiset nahkasiivet. Tammi, Helsinki.

Lintunen, JaRmo 2012: Laura Ruohosen näytelmä Suomies ei nuku ekosatiirina. Pro gradu -tutkielma. 
Jyväskylän yliopisto, Jyväskylä.

LiNTUNEN, JARMO 2017: "Maapallo Falskaa": Laura Ruohosen näytelmän Luolasto monimuotoinen dystooppisuus. Saija IsomaA ja Toni Lahtinen (toim.): Pakkovaltiosta ekodystopiaan - Kotimainen nykydystopia, 174-187. Joutsen: Erikoisjulkaisuja 2. Saatavissa http://urn.fi/URN:NBN:fife201705156413.

LummaA, Karolina 2010: Polittinen siivekäs: Lintujen konkreettisuus suomalaisessa 1970-luvun ympäristörunoudessa. Nykykulttuurin tutkimuskeskuksen julkaisuja. Vol. 102. Jyväskylän yliopisto, Jyväskylä.

_ 2013a: Luonnontieteellinen tieto lintuolemuksen rakentajana Alexis Kourosin Gondwanan lapsissa. Sananjalka, 201. Saatavissa http://elektra.helsinki.fi/se/s/o558-4639/55/luonnont.pdf.

2013b: Runous, ei-inhimillinen ja edustamisen politiikka. Ilona Hongisto ja Kaisa KurikKa (toim.): Toisin sanoin: Taiteentutkimusta representaation jälkeen, 79-109. Eetos, Turku.

LummaA, Karolinna - Rojola, Lea 2014: Johdanto: Mitä posthumanismi on? Karolinna LummaA ja Lea Rojola (toim.): Posthumanismi, 13-32. Eetos, Turku.

Luontoportti: Ankerias. Saatavissa http://www.luontoportti.com/suomi/fi/kalat/ankerias. [Viitattu 1.2.2018.]

Luontoportti: Metsähanhi. Saatavissa http://www.luontoportti.com/suomi/fi/linnut/metsahanhi. [Viitattu 13.12.2017.]

Malamud, Randy 2009 (2003): Poetic Animals and Animal Souls. Palgrave Macmillan, New York. https://doi.org/10.1007/978-1-137-06349-6

Mikкonen, Minttu 2017: "Kuudes sukupuutto" hävittää lajeja paljon pelättyä rajummin. Helsingin Sanomat, 27.10.2017.

Pfister, Manfred 1988: The theory and analysis of drama. European Studies in English Literature. Cambridge University Press, Cambridge.

Puchner, Martin 2010: The drama of ideas: Platonic provocations in theater and philosophy. Oxford University Press, Oxford.

REDLING, ELLEN 2014: New plays of ideas and an aesthetics of reflection and debate in contemporary British political drama. Journal of Contemporary Drama in English 2 (1), 159-169. Saatavissa http://www.degruyter.com/doi/10.1515/jcde-2014-0012. https://doi.org/10.1515/jcde-2014-0012

RuOHONen, LaUra 2004: Jälkisana. Teoksessa Kuningatar K ja muita näytelmiä. Otava, Helsinki. 2012: Sinne ja takaisin: Matka draaman maisemaan. PAula SAlminen ja Elina Snicker (toim.): Jumalainen näytelmä. Dramaturgisia työkaluja, 32-44. Like, Helsinki.

SimONs, JOHN 2002: Animal rights and the politics of literary representation. Palgrave, Basingstoke.

STEINBY, LIISA - TANSKANEN, KATRI 2013: Näytelmäkirjallisuus eli draama: Draaman analyysin peruskäsitteet. Aino MäKIKAlli ja LiISA SteInby (toim.): Johdatus kirjallisuusanalyysiin, 288-344. SKS, Helsinki.

Stephens Island wren. Saatavissa http://www.nzbirds.com/birds/stephenswren.html. [Viitattu 14.2.2018.] TÄHTINEN, Tero 2012: Eksyneitä eläimiä ja hitaita puita. Ympäristön politisoituminen suomalaisessa luontorunoudessa. Avain: Kirjallisuudentutkimuksen aikakauslehti (3): 34-48. https://doi. org/10.30665/av. 74878

TANSKANEN, KATRI 2017: Yleisö kohtaa toisen: Etiikan dramaturgioita 2010-luvun suomalaisissa näytelmissä. Helsingin yliopisto, Helsinki.

Wikipedia: Olmi. Saatavissa https://fi.wikipedia.org/wiki/Olmi. [Viitattu 26.1.2018.]

WWF: Kiljuhanhi. Saatavissa https://wwf.fi/elainlajit/kiljuhanhi/. [Viitattu 13.12.2017.]

YLÖNEN, IIRIS 2009: Kuningatar Kristiinan salaisuus: Kerronta ja sukupuolisuus Laura Ruohosen näytelmässä Kuningatar K. Pro gradu -tutkielma. Jyväskylän yliopisto, Jyväskylä. 


\section{JARMO LINTUNEN: Non-human animals as part of constructing a thesis play as found in three plays by Laura Ruohonen}

This article examines three contemporary plays by Laura Ruohonen from the point of view of constructing a thesis play. These plays are Lintu vai kala (Bird or Fish, 1992), Kuningatar K (Queen K, 2003) and Luolasto (The Cave 2014). The thesis play has traditionally been defined as a type of drama promoting a specific ideology that seeks to provide some sort of solution to a social problem. The ideology behind Ruohonen's plays lies in the critical handling of human and the environment. References to animals and nature are typical of Ruohonen's poetry. Animals in her plays are frequently featured in the dialogue and monologues, and I use the concept of animal dialogue on this feature. My article asks what does animal dialogue say about the relationship between humans and animals, animals themselves, and what kind of animal philosophy do these plays implement?

Animal philosophy examines animal-related philosophical questions where the animal is the primary target of research and not a mere instrument for determining humanity. Some animal philosophies emphasise the same features and ethical issues of both human and animal, while some emphasise their specialness and diversity. In addition, a third trend focusses on human being as an animal as well, thus trying to dismantle human-centred perceptions and structures.

The animal dialogues are emphasised in a slightly different way in each play, although common features are found. For example, there is a great deal of scientific knowledge about animals. Lintu vai kala emphasises ethical issues related to the protection and utilisation of animals. One of typical subject in Ruohonen's plays is critiquing of human activity. The animal dialogue in Kuningatar $K$ challenges the reader/viewer to reflect on the similarities between human and animal, as well as the differences between them. In addition, Kuningatar $K$ handles gender diversity issues in general. The animals appear to be active actors when encountering humans and cause change. In animal dialogues of Luolasto, in addition to the fact that human, for instance, forgets that he is an animal, the similarities between humans and animals are highlighted. The animal's perspective can also open up new opportunities for problematic situations. Luolasto suggests the potential extinction of animals and humans, unless humans change their actions.

From the perspective of the thesis play, the animal dialogue and animal activities bring different animal philosophical dimensions to the relationship between human and nature. In each play, the animals evoke different emotions (affective empathy). On the other hand, much scientific knowledge of animal appears in the plays, which also challenge the reader/viewer to reflect on their own perceptions and beliefs about animals (reflective empathy). In all the plays, tension is created between human and animal, which brings in a political dimension. Ruohonen seems to emphasise the fact that human is one of the animals among the others. On the other hand, she claims that human also has a great responsibility for other animals and for the continuation of life on our planet.

Jarmo Lintunen

japo.lintunen@gmail.com

Draamakasvatus

40014 Jyväskylän yliopisto 